\title{
EDUKASI GIZI DAN PEMBUATAN MENU PROGRAM MAKAN BERSAMA PADA IBU SISWA/I PENDIDIKAN ANAK USIA DINI
}

\author{
Retno Mardhiati \\ Prodi Kesehatan Masyarakat, Fakultas Ilmu-Ilmu Kesehatan, Universitas Muh. Prof. Dr. Hamka, Jakarta, \\ Indonesia \\ *Penulis Korespondensi: retno_ma@uhamka.ac.id
}

\begin{abstract}
Abstrak
Anak usia dini masih termasuk tahapan usia kehidupan yang rentan terhadap penyakit dan permasalahan kesehatan. Tahapan kehidupan usia 3-5 tahun sangat membutuhkan zat gizi yang menopang pertumbuhan dan perkembangan organ tubuh terutama otak. Oleh karena itu asupan makanan yang bergizi sangat penting diberikan untuk anak usia dini. Program Makan Bersama (PMB) merupakan salah satu program yang sering diadakan di PAUD, biasanya diselenggarakan setiap hari Jum'at. Pelaksanaan PMB ini bervariasi tiap PAUD, umumnya makanan dimasak oleh beberapa orang tua siswa/i, namun ada juga makanan dibawa oleh masing-masing siswa/i dari rumah. PMB yang dilaksanakan seringkali tidak sesuai dengan prinsip gizi seimbang dan bervariasi. Tujuan kegiatan yang dilakukan adalah melakukan edukasi gizi pada ibu siswa/i PAUD dan pembuatan menu makanan anak usia dini. Menu yang dibuat untuk diterapkan pada PMB di PAUD. Pembuatan menu makanan yang memenuhi prinsip gizi seimbang dan bervariasi. Metode dilapangan diawali dengan penyuluhan kebutuhan gizi anak usia dini dengan media Flip Chart terdiri edukasi zat gizi makro dan mikro, edukasi tentang komposisi piringku, dan pengarahan pembuatan menu makanan PMB. Hasil kegiatan, menu makanan yang disusun untuk PMB adalah Nasi Goreng Rilakuma, Nasi Ayam Teriyaki dan Telor Gulung, dan Fettucini Cambora. Setelah dievaluasi, semua peserta menyatakan kegiatan ini sangat bermanfaat dan meningkatkan pengetahuan orang tua siswa/i tentang gizi seimbang.
\end{abstract}

Kata kunci: Program Makan Bersama, PAUD, Gizi, Menu, Pendidikan Gizi

\begin{abstract}
Early childhood is considered as a phase of life that is susceptible to disease and health problem. At the age range of 3 to 5 years, nutrients that account for organ growth, particularly brain, is required. Therefore, it is very important to give children in their early childhood nutritious food intake. School Feeding Programme (SFP), abbreviated as SFP, is one of the program that is often held by Early Childhood Education Institution (ECEI), usually on Friday. The SFP administration is varied among ECEIs, but generally, some of the children's parents cook the meals for the program in the school, though in some other ECEIs the meals are brought by the children from home. Nevertheless, SFP implementation is often incompatible with balanced and varied diet principles. The purpose of activity conducted is to deliver nutritional education and to make menu that meets the balanced and varied diet principle for SFP in ECEIs. The method used in field includes socialization of nutrients needed for early childhood children using slides, giving education regarding macro and micronutrient, and directing on menu making for SFP. The activity generated a menu for SFP comprises Rilakuma Fried Rice, Chicken Teriyaki with Rice, Rolled Egg, and Cambora Fettuccini. After being evaluated, all of the participants stated that this activity is beneficial as it improved children's parrents' knowledge in respect of balanced nutrition.
\end{abstract}

Keywords: Eating Together Program, Early Childhood Education Institution, nutrition, menu, nutritional education.

\section{PENDAHULUAN}

Kebiasaan pola makan sehat dan sesuai dengan kebutuhan zat gizi, dimulai sejak dini. Hovdenak et al. (2019) menemukan kebiasaan makan tidak sehat di usia dini akan menjadi kebiasaan juga saat remaja. Luoto et al. (2019) juga menyatakan pola makan yang buruk akan menyebabkan gizi kurang atau gizi lebih pada
AUD. Jika AUD memiliki status gizi kurang atau gizi lebih akan memiliki risiko kesehatan dan mempengaruhi prestasi di PAUD (Murphey et al. 2011). Risiko kesehatan pada AUD antara lain gangguan perkembangan kognitif dan sosial, hal ini dapat diintervensi dengan nutrisi untuk pemulihan gangguan tersebut (Luoto et al. 2019; Hamadani et al. 2019). 
Fekadu et al. (2015) menyatakan kekurangan gizi selama 6 bulan dapat menyebabkan morbiditas, mortalitas, dan mengganggu perkembangan otak AUD.

Anak Usia Dini memiliki Indeks Makan Sehat rata-rata hanya $60 \%$, dimana AUD jarang mengkonsumsi sayuran dan kacang-kacangan hijau serta tinggi konsumsi makanan lemak jenuh PAUD (Murphey et al. 2011). Chen et al. (2019) juga menemukan kebiasaan AUD mengonsumsi makanan jenis karbohidrat per-hari mencapai 58,1 \%, makanan gula tinggi 94,8 \%, sedangkan sayur hanya $9,8 \%$, dan buah hanya $28 \%$.

Kebiasaan pola makan anak usia dini berhubungan dengan pengetahuan orang tua terutama ibu. Ibu memiliki peran penting dalam menyediakan makanan untuk anak usia dini (AUD). Faught et al. (2019) menyatakan tingkat ekonomi keluarga sebagai penentu utama kualitas ketersediaan makanan di keluarga. Ibu menyediakan makanan di rumah dipengaruhi oleh tingkat ekonomi keluarga. Santos et al. (2019) menyatakan ibu merupakan faktor paling konsisten yang terkait dengan indeks masa tubuh anak, dimana ibu yang obesitas cenderung memiliki anak yang juga obesitas.

Toussaint et al. (2019) menyatakan guru PAUD dapat mempromosikan makanan sehat kepada AUD dan orang tua siswa/i PAUD. Loveman et al. (2015) menyatakan intervensi edukasi gizi dan kesehatan pada orangtua, menjadi pilihan efektif untuk menurunkan masalah gizi dan kesehatan pada anak usia dini. Luoto et al. (2019) menyatakan intervensi edukasi gizi, dapat merubah perilaku orang tua dalam menyiapkan makanan untuk AUD. Hammersley et al. (2017) menyatakan keberhasilan edukasi gizi ke orang tua berpengaruh dalam indeks masa tubuh AUD.

Program Makan Bersama (PMB) merupakan salah satu program yang dilakukan di PAUD. Waktu pelaksanaan berdasarkan kesepakatan antara guru dan ibu siswa/i. Pelaksanaannya, salah satu ibu atau wali orang tua siswa/i memasak makanannya, kemudian dibagikan ke semua siswa/i di PAUD, dan semua siswa/i memakan bersama-sama. Permasalahan yang ada, ibu atau wali orang tua siswa/i serta guru PAUD belum memiliki pengetahuan kebutuhan dan kecukupan gizi untuk AUD. Makanan yang dimasak, sering kali tidak sesuai dengan prinsip gizi seimbang dan tidak bervariasi. Contoh makanan yang sering disajikan PMB antara lain mie goreng, bakso goreng, roti bakar. Makanan yang disajikan tinggi karbohidrat $(\mathrm{KH})$ dan rendah sayur dan buah. Makanan yang dibuat bersifat insidental dan menu makan tidak dirancang terlebih dahulu.

Berdasarkan latar belakang ini, ibu siswa/i sangat berperan dalam penyediaan makanan yang sehat di PMB. Tujuan kegiatan ini adalah melaksanakan edukasi gizi dan pembuatan menu makanan AUD pada ibu siswa/i PAUD.

\section{BAHAN DAN METODE}

Bahan yang digunakan terdiri dari media edukasi berupa gambar untuk penyuluhan, bahan mentah untuk pembuatan makanan terdiri dari nasi, Fettucinie, ayam, susu sapi, telor, tempe, tahu, brokoli, wortel, buncis, jagung, dan mentega. Buah sebagai pelengkap menu makanan yakni apel, naga, dan jeruk manis.

Pelaksanaan kegiatan ini dilakukan 4 tahap yaitu pembuatan materi edukasi gizi AUD, pemberian edukasi pada ibu siswa/i PAUD tentang Kebutuhan dan Kecukupan Gizi AUD, Penyusunan perencanaan menu makanan dan demo makanan. Mitra kegiatan ini adalah PAUD Penyejuk Mata Srengseng Sawah, Jagakarsa. Kegiatan ini melibatkan partisipasi mitra dalam setiap kegiatan PKM adalah menyiapkan sarana dan prasaran kegiatan seperti ruangan dan peralatan yang dibutuhkan. Kegiatan ini dilakukan pada bulan Februari 2019.

Tahap pertama dilakukan pembuatan materi KIE. Materi KIE meliputi prinsip gizi seimbang, mengukur status gizi AUD, dampak status gizi tidak normal, kebutuhan zat gizi makro dan mikro AUD serta komposisi piringku. Tahap kedua, adalah pelaksanaan KIE pada ibu siswa/i PAUD tentang Kebutuhan dan Kecukupan Gizi AUD. Kegiatan dilakukan dengan media gambar ukuran A3, yang ditunjukkan pada peserta. Tahap kedua ini, juga dilakukan diskusi serta tanya jawab. Tahap ketiga, penyusunan menu untuk PMB. Menu yang disusun untuk 2 waktu pelaksanaan PMB yakni PMB saat sarapan dan PMB saat makan siang. Tahap keempat, dilaksanakan demo makanan AUD yang diikuti oleh ibu siswa/i PAUD dan guru PAUD.

Evaluasi keberhasilan edukasi gizi pada ibu siswa/i PAUD dilakukan dengan memberikan lembar penilaian manfaat kegiatan pada ibu siswa/i PAUD. Evaluasi kegiatan penyusunan menu makanan dan pembuatan makanan dilakukan dengan memberikan lembar penilaian terhadap kegiatan praktikum tersebut meliputi pengetahuan gambaran takaran dan bahan makanan, pengetahuan zat gizi makanan, dan cara penyajian makanan untuk AUD.

\section{HASIL DAN PEMBAHASAN}

Edukasi gizi pada ibu siswa/i merupakan hal yang penting dilakukan, hal ini dikarenakan ibu memiliki lebih banyak waktu untuk memperhatikan perkembangan dan pertumbuhan AUD dibandingkan seorang ayah. Selain itu juga, ibu yang memiliki tugas penyediaan makanan di rumah. PMB yang sering diselenggarakan di PAUD, merupakan hal yang baik untuk mengenalkan makanan-makanan yang bergizi pada AUD. Hal ini sejalan dengan Diab (2015) yang menyatakan AUD menjadi tahapan waktu yang penting untuk pengembangan perilaku makanan dan pola makan yang baik. PAUD menjadi tempat yang sempurna untuk mengenal prinsip nutrisi AUD untuk orang tua dan guru.

Ibu siswa/i yang menyediakan atau memasak makanan untuk PMB yang dilakukan di PAUD Penyejuk Mata. 
Pengetahuan gizi AUD yang baik dan keterampilan dalam mengolah makanan menjadi hal penting untuk ibu siswa/i yang bertugas membantu penyelenggaraan PMB.

Program Kegiatan Masyarakat ini diawali dengan merancang materi edukasi gizi untuk ibu siswa/i PAUD. Materi edukasi gizi terdiri dari 30 gambar dengan isi materi meliputi prinsip gizi seimbang, mengukur status gizi AUD, dampak status gizi tidak normal, kebutuhan zat gizi makro dan mikro AUD serta komposisi piringku. Saat edukasi gizi berlangsung, peserta aktif bertanya dan berdiskusi tentang permasalahan makan pada AUD. Kebiasaan AUD yang cenderung tidak suka sayur dan memilih makanan.

Makanan yang dibuat memenuhi prinsip bergizi seimbang dan bervariasi. Hal ini juga dikemukan oleh Hu et al. (2019) yang menyatakan pola makan AUD yang baik dianjurkan makanan yang seimbang dan bervariasi, menghindari kebiasaan makanan instan dan makanan manis, makanan yang mudah disiapkan. Mohammaed et al. (2019) juga menyatakan pertumbuhan linier AUD berhubungan secara positif dengan keragaman makanan dan konsumsi suplementasi vitamin. Keragaman makanan dan gizi seimbang menjadi acuan dalam pembuatan menu makanan dan penyediaan makanan AUD.

Gizi seimbang adalah susunan pangan sehari-hari yang mengandung zat gizi dalam jenis dan jumlah yang sesuai dengan kebutuhan tubuh. Ada 4 Pilar Gizi Seimbang yakni mengonsumsi makanan berragam, Membiasakan perilaku hidup bersih, melakukan aktivitas fisik dan mempertahan dan memantau berat badan normal. Dalam materi "Isi Piringku" terdiri dari makanan pokok, lauk pauk, sayuran, dan buah-buahan.
Hal lain yang juga ada materi lain seperti materi kebiasaan aktivitas fisik 30 menit per hari, minum air 8 gelas sehari, mencuci tangan dengan sabun dan air mengalir.

Keseimbangan zat gizi yang dikonsumsi oleh siswa/i PAUD digunakan untuk pertumbuhan, perkembangan, kecerdasan, aktifitas dan menjaga kesehatan. Makanan yang diberikan pada siswa/i PAUD memenuhi Prinsip Gizi Seimbang. Keseimbangan zat gizi yang masuk lewat makanan dan minuman yang dikonsumsi dengan zat gizi yang dibutuhkan oleh tubuh. Ada 4 Pilar Gizi Seimbangan yaitu mengkonsumsi makanan beragam, membiasakan perilaku hidup bersih, melakukan aktivitas fisik, mempertahankan dan memantau berat badan normal (Kementerian Kesehatan RI, 2014).

Kebutuhan zat gizi per-hari pada anak usia 3-5 tahun dengan berat badan $13 \mathrm{~kg}$ dan tinggi badan $91 \mathrm{~cm}$ yakni energi 1125 kkal, karbohidrat 155 gram, protein 26 gram, lemak 44 gram. Sedangkan kebutuhan zat gizi per-hari pada anak usia 4-6 tahun dengan berat badan 19 $\mathrm{kg}$ dan tinggi badan $112 \mathrm{~cm}$ yakni energi $1600 \mathrm{kkal}$, karbohidrat 220 gram, protein 35 gram, lemak 62 gram (Persatuan Ahli Gizi Indonesia, 2009).

Kegiatan dilanjutkan dengan perencanaan menu. Perencanaan menu adalah serangkaian kegiatan menyusun dan memadukan hidangan dalam variasi yang serasi, harmonis yang memenuhi kecukupan gizi, cita rasa yang sesuai dengan selera konsumen. Menu yang dibuat merujuk pada kebutuhan zat gizi AUD, memiliki unsur variasi dan seimbang, menghindari makanan yang memiliki duri atau tulang, dan dilengkapi sayur serta buah. Perencanaan menu untuk PMB PAUD Penyejuk Mata, menghasilkan 3 menu yakni nasi goreng Rilakuma, Ayam teriyaki, dan Fettucini Carbonara.

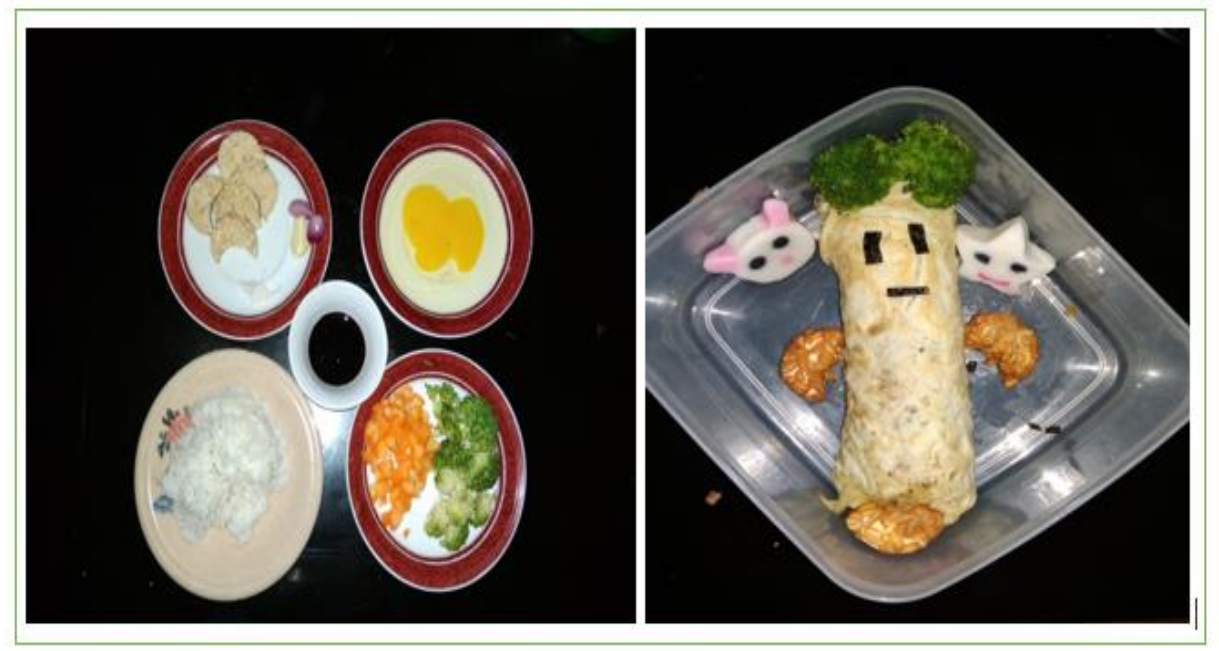

Gambar 1. Bahan dan Hasil Pembuatan Nasi Goreng Rilakuma.

Nasi goreng Rilakuma salah satu makanan popular di masyarakat yang disajikan dalam bentuk beruang lucu atau beruang yang bersantai. Bahan dasar pembuatan Nasi Goreng Rilakuma terdiri dari nasi, wortel, brokoli, telor, tempe, bawang merah, bawang putih, dan kecap serta untuk hiasan digunakan adonan seafood berbentuk gambar. Nasi goreng Rilakuma memiliki kandungan energi, karbohidrat, sayur diwakili oleh wortel dan brokoli, kandungan protein diwakili oleh tempe dan telor. Makanan yang disajikan 
dengan bentuk yang unit akan meningkatkan nafsu makan anak PAUD. Gambar 1 menampilkan bahan dan takaran untuk pembuatan Nasi Rilakuma sebagai berikut :

$\begin{array}{ll}\text { Nasi } & 100 \mathrm{gr} / 1 \text { centong } \\ \text { Telur ayam } & 55 \mathrm{gr} / 1 \text { butir } \\ \text { Tempe } & 25 \mathrm{gr} / 1 \text { potong } \\ \text { Wortel } & 25 \mathrm{gr} / 2 \mathrm{sdm} \\ \text { Brokoli } & 25 \mathrm{gr} / 2 \mathrm{sdm}\end{array}$

Pelengkap hidangan :

Apel $85 \mathrm{gr} / 1$ buah
Kandungan zat gizi makro nasi goreng Rilakuma sudah memenuhi kebutuhan per-hari energi $\pm 20 \%$, karbohidrat $\pm 16 \%$, kebutuhan protein $\pm 43,14 \%$, dan kebutuhan lemak $\pm 21 \%$ untuk AUD yang berumur 4 6 tahun dengan berat badan $19 \mathrm{~kg}$ dan tinggi badan 112 $\mathrm{cm}$.

Tabel 1. Kandungan Zat Gizi Makro Nasi Goreng Rilakuma.

\begin{tabular}{llrrrrr}
\hline \multirow{2}{*}{ Menu } & Bahan Makanan & \multicolumn{1}{c}{$\begin{array}{c}\text { Berat } \\
(\mathbf{g r})\end{array}$} & $\begin{array}{c}\text { Energi } \\
\text { (kkal) }\end{array}$ & $\begin{array}{c}\text { Protein } \\
\text { (gr) }\end{array}$ & $\begin{array}{c}\text { Lemak } \\
\text { (gr) }\end{array}$ & KH (gr) \\
\hline \multirow{2}{*}{ Nasi Goreng } & Nasi Putih & 100 & 130 & 2,4 & 0,2 & 28,6 \\
Rilakuma & Telur Ayam & 55 & 85,3 & 6,9 & 5,8 & 0,6 \\
& Tempe & 25 & 49,8 & 4,8 & 1,9 & 4,3 \\
& Wortel & 25 & 6,5 & 0,2 & 0,1 & 1,2 \\
& Brocoli & 25 & 5,8 & 0,8 & 0 & 0,5 \\
& Minyak & 5 & 43,1 & 0 & 5 & 0 \\
Buah & & & & & & \\
& & & 50,2 & 0,2 & 0,3 & 13 \\
\hline Total zat gizi makro & & & $\mathbf{3 7 0 , 7}$ & $\mathbf{1 5 , 3}$ & $\mathbf{1 3 , 3}$ & $\mathbf{4 8 , 2}$ \\
\hline
\end{tabular}

Makanan ke 2 yang dibuat adalah Nasi ayam Teriyaki dan Dadar Gulung Wortel. Bahan dasar makanan ke 2 ini terdiri dari ayam, bumbu teriyaki, bawang putih, mentega, garam, kecap, sayur selada dan telor. Penyajian makanan ditambah dengan buah naga 100 gram.
Gambar 2, bahan dan takaran untuk pembuatan Nasi Ayam Teriyaki sebagai berikut :
Nasi Putih
Ayam Teriyaki
$100 \mathrm{gr} / 1$ centong
$40 \mathrm{gr} / 1$ potong

$\begin{array}{ll}\begin{array}{l}\text { Rolade Tahu Sayur } \\ \text { Tahu }\end{array} & 50 \mathrm{gr} / 1 \text { potong } \\ \text { Telur } & 55 \mathrm{gr} / 1 \mathrm{butir} \\ \text { Wortel } & 40 \mathrm{gr} / 3 \mathrm{sdm}\end{array}$

Pelengkap hidangan :

Buah Naga100 gr/ 1/2 potong

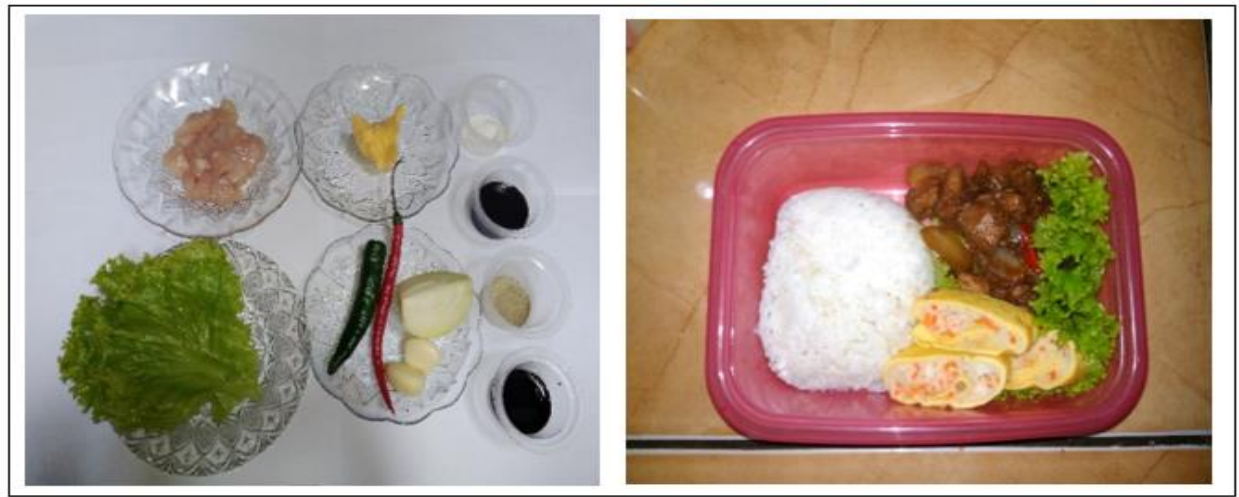

Gambar 2. Bahan dan Hasil Pembuatan Nasi Ayam Teriyaki dan Dadar Gulung Wortel.

Telor gulung yang sudah dicampur dengan wortel dapat menarik perhatian siswa/i PAUD. Bagi siswa/i yang tidak suka wortel secara terpisah, dapat disajikan dengan mencampurkan dengan telor dadar gulung. Daun selada biasanya hanya digunakan untuk menghiasi sajian makanan. Jarang sekali siswa/i yang mengkonsumsi daun selada sebagai sayuran saat makan. Menu nasi ayam teriyaki dan telor gulung, merupakan menu yang memasukan sayuran wortel dan sayur slada dalam olahan makanan sehingga anak yang kurang sayur, dapat tetap mengkonsumsi sayur tanpa menyadari adanya keberadaan sayuran tersebut. Bahan 
dan takaran disesuaikan dengan kebutuhan anak usia 46 tahunKandungan zat gizi makro Nasi ayam Teriyaki dan Dadar Gulung Wortel sudah memenuhi kebutuhan per-hari energi $\pm 28 \%$, karbohidrat $\pm 14,5 \%$, kebutuhan protein $\pm 70,3 \%$, dan kebutuhan lemak $\pm 39 \%$ untuk AUD yang berumur 4-6 tahun dengan berat badan $19 \mathrm{~kg}$ dan tinggi badan $112 \mathrm{~cm}$.

Tabel 2. Kandungan Zat Gizi Makro adalah Nasi Ayam Teriyaki dan Dadar Gulung Wortel.

\begin{tabular}{|c|c|c|c|c|c|c|}
\hline Menu & Bahan Makanan & $\begin{array}{c}\text { Berat } \\
\text { (gr) }\end{array}$ & $\begin{array}{c}\text { Energi } \\
\text { (kkal) }\end{array}$ & $\begin{array}{c}\text { Protein } \\
\text { (gr) }\end{array}$ & $\begin{array}{c}\text { Lemak } \\
\text { (gr) }\end{array}$ & KH (gr) \\
\hline Nasi Putih & Nasi Putih & 100 & 130 & 2,4 & 0,2 & 28,6 \\
\hline \multirow[t]{2}{*}{ Ayam Teriyaki } & Daging Ayam & 40 & 114 & 10,8 & 7,6 & 0 \\
\hline & Mentega & 10 & 71 & 0 & 8,1 & 0 \\
\hline \multirow[t]{3}{*}{ Rolade Tahu } & Tahu & 50 & 38 & 4,1 & 2,4 & 0,9 \\
\hline & Telur Ayam & 55 & 85,3 & 6,9 & 5,8 & 0,6 \\
\hline & Wortel & 40 & 10,3 & 0,4 & 0,1 & 1,9 \\
\hline Buah & Naga & 100 & 51 & 0,78 & 0,38 & 12,38 \\
\hline Total zat gizi n & & & 499,6 & 25,38 & 24,58 & 44,38 \\
\hline
\end{tabular}

Makanan yang ke 3 yang dibuat adalah Fettucini Carbonara, yang juga berisi limpah ayam dan sayur. Makanan ini juga sudah sering dibuat oleh ibu-ibu rumah tangga. Makanan yang ke 3 ini dapat diberikan pada siswa/i yang tidak suka sayur dalam penyajian terpisah. Dengan mencampur sayuran buncis, wortel dan jagung pada Fettucini.

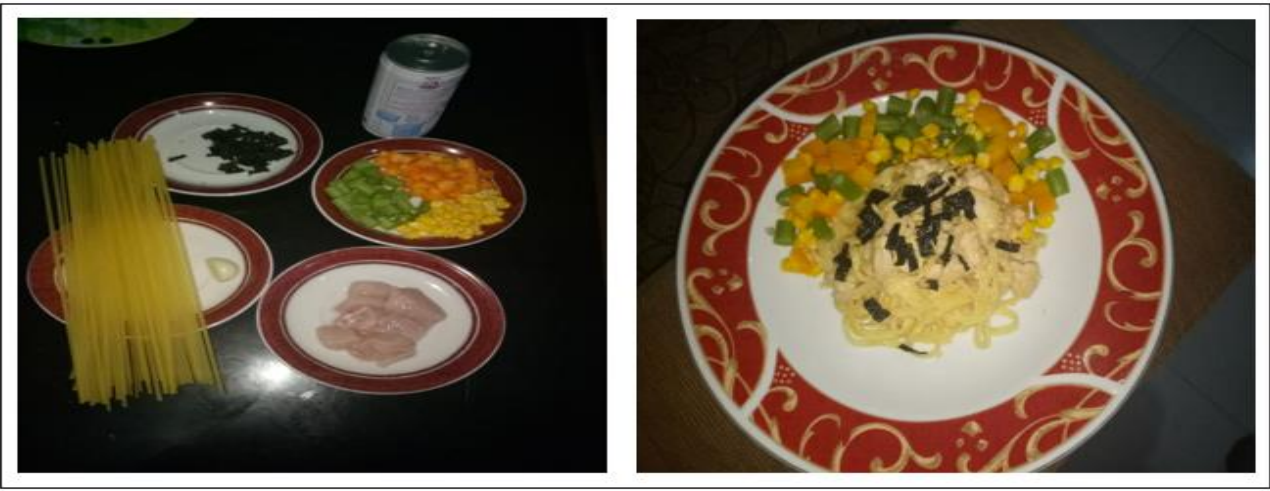

Gambar 3. Bahan dan Hasil Pembuatan Fettucini Carbonara.

Gambar 3, bahan dan takaran untuk pembuatan Fettucini Carbonara sebagai berikut :
Fettucini

Susu Sapi

Smoke beef

Tumis wortel buncis jagung

Wortel

Buncis

Jagung

Pelengkap Hidangan :

Buah Jeruk $55 \mathrm{gr} / 1$ buah
$50 \mathrm{gr} / 1$ mangkok $100 \mathrm{gr} / 1 / 2$ gelas $20 \mathrm{gr} / 2$ lembar

$10 \mathrm{gr} / 1 \mathrm{sdm}$

$10 \mathrm{gr} / 1 \mathrm{sdm}$

$10 \mathrm{gr} / 1 \mathrm{sdm}$
Kandungan karbohidrat ada pada Fettucini, kandungan energi pada Fettucini dan minyak dan susu yang digunakan. Protein diperoleh dari ayam. Vitamin dan mineral diperoleh dari sayuran buncis, wortel dan jagung. Menu ketiga menggunakan bahan dasar bukan beras. Hal ini untuk memberikan variasi makanan pada anak PAUD. Dicampur dengan wortel dan buncis serta jagung untuk memenuhi kebutuhan serat makanan. Kandungan zat gizi makro Fettucinie Carbonara sudah memenuhi kebutuhan per-hari energi $\pm 21 \%$, karbohidrat $\pm 14,3 \%$, kebutuhan protein $\pm 52,6 \%$, dan kebutuhan lemak $\pm 23 \%$ untuk AUD yang berumur 4-6 tahun dengan berat badan $19 \mathrm{~kg}$ dan tinggi badan 112 $\mathrm{cm}$. 
Tabel 3. Kandungan Zat Gizi Makro adalah Fettucinie Carbonara.

\begin{tabular}{|c|c|c|c|c|c|c|}
\hline Menu & Bahan Makanan & $\begin{array}{c}\text { Berat } \\
\text { (gr) }\end{array}$ & $\begin{array}{c}\text { Energi } \\
\text { (kkal) }\end{array}$ & $\begin{array}{c}\text { Protein } \\
\text { (gr) }\end{array}$ & $\begin{array}{c}\text { Lemak } \\
\text { (gr) }\end{array}$ & $\begin{array}{l}\text { KH } \\
\text { (gr) }\end{array}$ \\
\hline \multirow{6}{*}{$\begin{array}{l}\text { Fettucinie } \\
\text { Carbonara }\end{array}$} & Fettucinie & 40 & 130 & 3,8 & 2,6 & 22,6 \\
\hline & Daging Ayam & 40 & 114 & 10,8 & 7,6 & 0 \\
\hline & Susu Sapi & 100 & 66 & 3,2 & 3,9 & 4,8 \\
\hline & Wortel & 12,5 & 3,2 & 0,1 & 0 & 0,6 \\
\hline & Buncis & 12,5 & 4,4 & 0,2 & 0 & 1 \\
\hline & Jagung & 10 & 10,8 & 0,3 & 0,1 & 2,5 \\
\hline Buah & Jeruk Manis & 110 & 51,8 & 1 & 0,1 & 13 \\
\hline \multicolumn{2}{|c|}{ Total zat gizi makro } & & 380,2 & 19,4 & 14,3 & 44,5 \\
\hline
\end{tabular}

Pelaksanaan PMB tidak sama disetiap PAUD, namun umumnya makanan dibuat oleh ibu-ibu siswa/i PAUD. Banyak pertanyaan yang diajukan oleh peserta saat sesi diskusi dan tanya jawab. Hampir $80 \%$ peserta memberikan pertanyaan seputar trik yang membuat anak menyukai sayuran. Terkadang anak tidak mau makan atau memilih-milih makanan, juga menjadi bahan diskusi. Ibu-ibu juga menyatakan kegiatan edukasi berkaitan dengan gizi anak usia dini sebaiknya bersifat rutin dan kontinyu dengan topik yang berbedabeda.

Proses pembuatan makanan dengan prinsip gizi seimbang dan bervariasi atau keragaman juga menjadi hal yang baru bagi peserta, selama ini ibu-ibu masih berpikir poma 4 sehat 5 seimbang. Peningkatan pengetahuan dengan metode pembuatan menu untuk PMB menjadi strategi untuk menarik perhatian dan focus ibu-ibu dalam edukasi gizi. Peran ibu yang besar sangat baik ditunjang dengan pengetahuan tentang gizi AUD yang baik juga. Fekadu et al. (2015) menyatakan orang tua atau ibu sangat membutuhkan pengetahuan tentang keragaman makanan dan pemberian makanan yang tepat.

Belew et al. (2017) menyatakan semua ibu harus berpartisipasi dalam program pemantauan pertumbuhan AUD dengan memperhatikan penyediaan makanan dan kesesuaikan komposisi makanan sesuai dengan kebutuhan dan kecukupan zat gizi. Hal ini dikarenakan jumlah, frekuensi, dan kualitas pemberian makanan yang kurang memadai memiliki efek negatif pada kesehatan dan pertumbuhan AUD. Besar keragaman makanan AUD hanya 17\% dan frekuensi makanan yang baik hanya $72,2 \%$.

Dalam kegiatan ini, membuat menu makanan AUD menjadi salah satu daya tarik peserta untuk lebih memperhatikan asupan makan AUD. Keberhasilan kegiatan edukasi gizi dan praktek membuat menu makan AUD akan memberikan kontribusi yang positif untuk keberlangsungan PMB di PAUD.

Capaian kegiatan ini dapat dilihat dari evaluasi kegiatan, dimana semua peserta (100\%) menyatakan kegiatan edukasi gizi AUD sangat bermanfaat dan menambah pengetahuan tentang kebutuhan gizi AUD. Capaian kegiatan pembuatan menu makanan AUD juga baik, dimana semua peserta (100\%) menyatakan kegiatan pembuatan menu memberikan gambaran takaran dan bahan makanan serta pengetahuan kandungan zat gizi makro (karbohidrat, protein, lemak) dan zat gizi mikro (vitamin dan mineral) serta praktek mengkreasikan penyajian makanan untuk meningkatkan daya tarik AUD dalam menyantap makanannya.

\section{KESIMPULAN}

Kegiatan ini dinyatakan berhasil dan bermanfaat, dengan kesimpulan sebagai berikut :

1) Rancangan materi edukasi gizi telah selesai dilakukan meliputi prinsip gizi seimbang, mengukur status gizi AUD, dampak status gizi tidak normal, kebutuhan zat gizi makro dan mikro AUD serta komposisi piringku.

2) Semua peserta (100\%) menyatakan kegiatan edukasi gizi ini sangat bagus dan bermanfaat. Semua peserta $(100 \%)$ terlibat dalam diskusi dan tanya jawab. Kegiatan pembuatan menu makanan AUD juga 100 $\%$ dinyatakan sangat baik dan bermanfaat oleh peserta.

3) Penyusunan menu untuk PMB ada 3 makanan Nasi Goreng Rilakuma, Nasi Ayam Teriyaki dan Telor Gulung, dan Fettucini Carbora. Menu didemokan dalam bahan dan takaran serta hasil makanan yang sudah dihiasi untuk meningkatkan motivasi AUD untuk makan.

\section{SARAN}

Kegiatan pengabdian masyarakat edukasi gizi AUD dilaksanakan sebagai kegiatan rutin dan berkelanjutan dalam bentuk pendampingan dan pembinaan PMB di PAUD-PAUD. Adanya perhatian dan kepedulian gizi AUD, diupayakan PMB yang dilaksanakan sesuai dengan angka kebutuhan dan kecukupan gizi untuk AUD.

\section{UCAPAN TERIMA KASIH}

Ucapan terima kasih terutama ditujukan kepada Lembaga Pengabdian dan Pemberdayaan Masyarakat Universitas Muhammadiyah Prof. Dr. Hamka yang telah mendanai kegiatan ini. Ucapan terima kasih dapat juga disampaikan kepada Ketua PAUD Penyejuk Mata 
Srengseng Sawah-Jagakarsa yang telah bersedia menjadi mitra kegiatan pengabdian masyarakat. Ucapan terima kasih juga pada pihak-pihak yang membantu pelaksanaan pengabdian masyarakat ini.

\section{DAFTAR PUSTAKA}

Belew, A. K., Ali, B. M., Abebe, Z., Dachew, B. A. (2017). Dietary Diversity and Meal Frequency Among Infant and Young Children: A Community Based Study. Ital J Pediatr, 43(1), 73-80.

Chen, L. W., Fung, S. M., Fok, D., Leong, L. P., Toh, J. Y., Lim, H. X., Pang, W. W., Tan, K. H., Chong, Y. S., Yap, F., Godfrey, K. M., Lee, Y. S., Chong, M. F. F. (2019). The Development and Evaluation of a Diet Quality Index for Asian Toddlers and Its Perinatal Correlates: The GUSTO Cohort Study. Nutrients, 11(535), 1-19.

Diab, S. S. E. M. (2015). Effect of Nutritional Guideline for Kindergarten Teachers on Healthy Physical Growth of Preschool Children. IOSR Journal of Research \& Method in Education, 5(4), 17-25.

Faught, E. L., McLaren, L., Kirkpatrick, S. I., Hammond, D., Minaker, L. M., Minaker, L. M., Raine, K. D., Olstad, D. L. (2019). Socioeconomic Disadvantage Across The Life Course is Associated with Diet Quality in Young Adulthood . Nutrients, 11, 242-247.

Fekadu, Y., Mesfin, A., Haile, D., Stoecker, B. J. (2015). Factors Associated with Nutritional Status of Infants and Young Children in Somali Region, Ethiopia: A Cross- Sectional Study. BMC Public Health, 2(15), 846-853.

Hamadani, J. D., Mehrin, S. F., Tofail, F., Hasan, M. I., Huda, S. N., Baker-Henningham, H., Ridout, D., Grantham-McGregor, S. (2019). Integrating an Early Childhood Development Programme into Bangladeshi Primary Health-Care Services: an Open-Label, Cluster-Randomised Controlled Trial. Lancet Glob Health, 7(3), e366-e375.

Hammersley, M. L., Jones, R. A., Okely, A. D. (2017). Time2bHealthy - an Online Childhood Obesity Prevention Program for Preschool-Aged Children: a Randomised Controlled Trial Protocol. Contemp Clin Trials, 61, 73-80.

Hovdenak, I. M., Stea, T. H., Twisk, J., Te Velde, S. J., Klepp, K. I., Bere, E.. (2019). Tracking of Fruit, Vegetables and Unhealthy Snacks Consumption From Childhood to Adulthood (15 Year Period): Does Exposure to a Free School Fruit Programme Modify The Observed Tracking? Int J Behav Nutr Phys Act, 16(1), 22-29.

Hu, S., Sim, Y. F., Toh, J. Y., Saw, S. M., Godfrey, K. M., Chong, Y. S., Yap, F., Lee, Y. S., Shek, L. P., Tan, K. H., Chong, M. F., Hsu, C. S. (2019). Infant Dietary Patterns and Early Childhood Caries in a Multi-Ethnic Asian Cohort. Sci Rep., 9(1), 852-857.

Kementerian Kesehatan RI. (2014). Pedoman Gizi Seimbang. Jakarta: Kementerian Kesehatan RI.
Loveman, E., Al-Khudairy, L., Johnson, R. E., Robertson, W., Colquitt, J. L., Mead, E. L., Ells, L. J., Metzendorf, M. I., Rees, K. (2015). Parent -Only Interventions for Childhood Overweight or Obesity in Children Aged 5-11 Years. Cochrane Database Syst Rev, 21(12), CD12008.

Luoto, J. E., Lopez, G. I., Aboud, F. E., Fernald, L. C. H., Singla, D. R. (2019). Testing Means to Scale Early Childhood Development Interventions in Rural Kenya: The Msingi Bora Cluster Randomized Controlled Trial Study Design and Protocol. BMC Public Health, 19(1), 259-267.

Mohammed, S. H., Habtewold, T. D., Tegegne, B. S., Birhanu, M. M., Sissay, T. A., Lariani, B., Esmaillzadeh, A. (2019). Dietary and NonDietary Determinants of Linear Growth Status of Infants and Young Children in Ethiopia: Hierarchical Regression Analysis. PLoS One, 14(1), e0209220.

Murphey, D., Mackintosh, B., McCoy-Roth, M. (2011). Early Childhood Policy Focus: Healthy Eating and Physical Activity. Early Chilhood Highlights, 2(3), 1-9.

Persatuan Gizi Indonesia. (2009). Tabel Komposisi Pangan Indonesia. Jakarta : PT Elex Media Komputindo.

Santos, L. P., Santos, I. S., Matijasevich, A., Barros, A. J. D. (2019). Changes in Overall and Regional Body Fatness from Childhood to Early Adolescence. Sci Rep, 9(1), 1888-1895.

Toussaint, N., Streppel, M. T., Mul, S., Schreurs, A., Balledux, M., Drongelen, K. V., Janssen, M., Fukkink, R. G., Weijs, P. J. M. (2019). A Preschool-Based Intervention for Early Childhood Education and Care (ECEC) Teachers in Promoting Healthy Eating and Physical Activity in Toddlers: Study Protocol of The Cluster Randomized Controlled Trial Preschool@Healthy Weight. BMC Public Health, 19(1), 278-282. 